\title{
AUTO-CONSTRUCTION REDUX: The City as Method
}

\author{
ALBERTO CORSÍN JIMÉNEZ \\ Spanish National Research Council (CSIC) \\ (D) http: / / orcid.org/0000-0002-1360-4060
}

"A monumental tool," someone whispered. "Hundreds of pages long," someone else noted. "The Processgram," a third person finally glossed, while providing a description that functioned as both nomenclature and mythical signature. It must have been 2011 or 2012 when I first heard these words, and the images they provoked have stayed with me ever since. I was mesmerized. It had never occurred to me that guerrilla architectural collectives might have developed a project management tool with a view to registering every action, every bifurcation, every photograph and drawing and sketch, every failure and insight garnered during a community project. At once a self-made archive and a social design interface, an organizational program and an urban directory, here was a tool that architects were using for auto-constructing the city (for building social and material relations) at the same time as they auto-constructed their methods.

The project in question was Autobarrios (literally, Auto-neighborhoods), a social community initiative led by the guerrilla architectural collective Basurama in San Cristóbal de los Ángeles, one of Madrid's poorest and most disenfranchised neighborhoods. ${ }^{1}$ First initiated by Juan López Aranguren and Sarah Fernández Deutsch, the former a member of Basurama who had himself grown up in the community, the project signaled a departure from the collective's history of participatory and critical art interventions. On the cusp of the financial crisis, Aran- 
guren took on the project when the very existence of Basurama was under threat. The art and architectural collective, which only a year back had curated Madrid's White Night (the preeminent summer arts festival in the city), was undergoing a profound personal, economic, and professional crisis. Basurama had measured up to the challenge of curating the event with a sardonic, yet constructive proposition for engaging the ludic pulsations of (the) capital. "Place Your Bets!," as they called the festival, took residence in the city's main arteries and public spaces by employing trash and discarded materials (the signature of Basurama's artwork) in the transformation of the cityscape into a gigantic open-air playground and amusement park. The installations thus built were designed to be dismantled and recycled for future use in the auto-construction of urban equipment in peripheral and marginal communities in Madrid's hinterland (see figures 1 and 2). However, the responsibility for curating White Night - a symbol, if there ever was one, of the "process of branding-based urban regeneration . . . complicit in the neoliberal attitude to the city" (McGuirk 2014, 15) that characterized the architecture of spectacle and capital of recent Spanish urbanization-had split the collective. Taking place in September 2010, just as the first wave of the financial crisis had sunk in and the miracle bubble of the Spanish real-estate economy burst, Basurama's playful romance with the economics of desire drew little sympathy and took far too many punches, not least from radical and countercultural collectives who viewed Basurama's involvement as a disappointing sellout to the seductions of capital. The city placed its bets, knocking Basurama out. In the event's aftermath some members left the collective, while others took a break and those remaining faced a glum horizon of precarity and depression. In this context, Aranguren set out to San Cristóbal with a project that was part therapy, part desperation, part calling. Autobarrios was conceived as a free-fall immersion into the conditions that shape autonomy as a practical design and political challenge in contexts of marginalization - where the use of the auto label gestured to the vague promises of both community and material self-emancipation.

As it happens, I never got to see the Processgram, although I encountered different versions of it over the following five years. I never saw the object, but I became party to the method. The method Basurama developed for Autobarrios became an important practice for their work elsewhere, in abandoned sites and allotments, working in collaboration with schools and neighborhood associations, in partnership with cultural institutions, other architectural collectives, or indeed academics such as myself. The method seemed to travel widely. Over time, however, I came to question this perception of the method as a traveling object. 


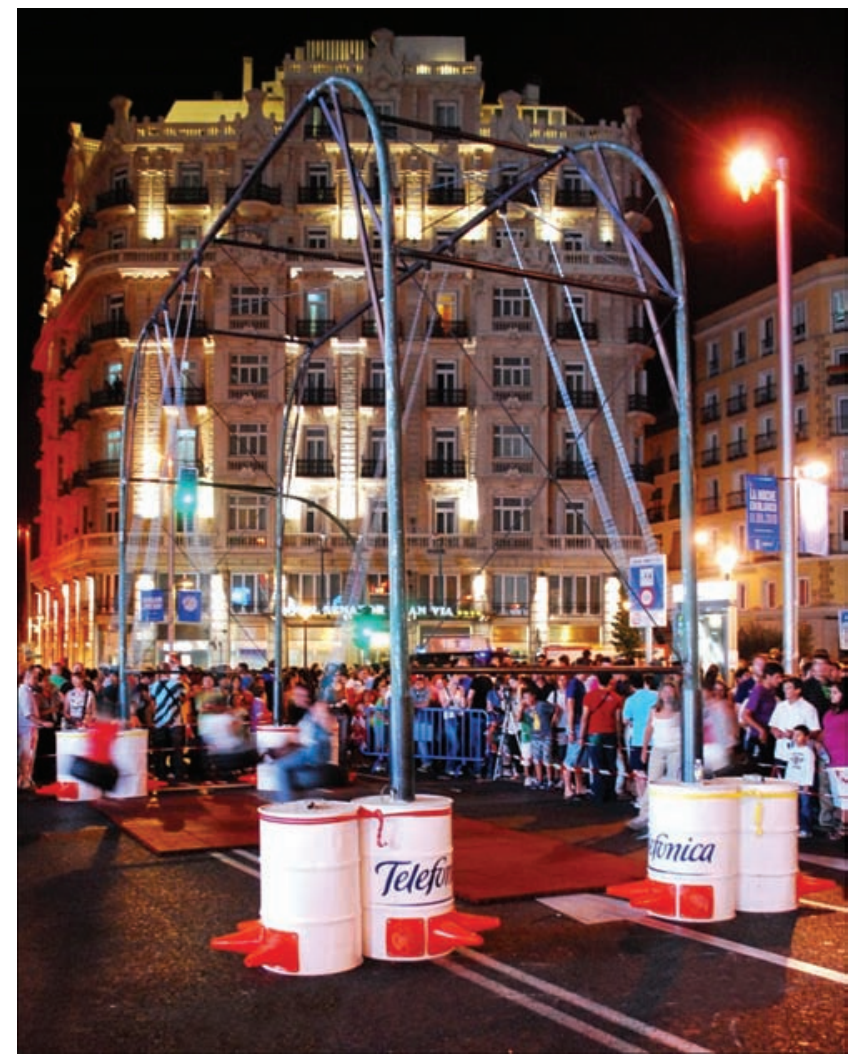

Figure 1. Giant swing, La Noche en Blanco, September 2010. Photo by Zuloark.

There seemed to be too much method everywhere. What if it was not the method itself that traveled as much as a particular cultural sensorium and material aesthetic? What if it was an emerging experience of the city as method that one encountered everywhere - if method was an infrastructure of feeling for the city? ${ }^{2}$

This article develops an ethnographic argument about the experience of method as a modality of relationality in Madrid. Building on more than six years of fieldwork with guerrilla architectural collectives, community activists, artists, and neighborhood associations in the city, I report on the use that these collectives make of the method of auto-construction as a perceptual and material system for sharing resources, knowledge, and experiences. The method of auto-construction has become a placeholder for how grassroots projects think and feel and grab hold of the city as a horizon of hope and responsibility, of intimacy and action. At a time of crisis and desperation, auto-construction has provided a faithful and intuitive idiom for movements of aspiration and autonomy, for shifting 


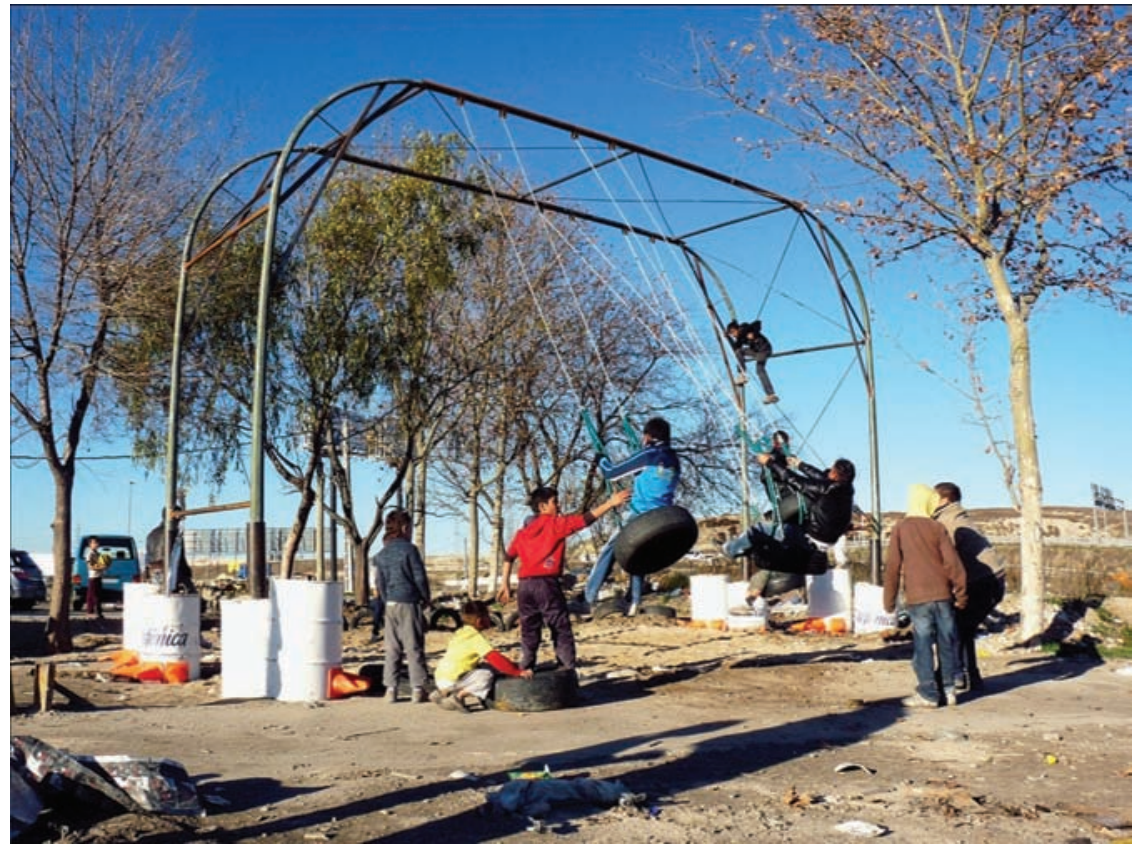

Figure 2. Giant swing recycled at El Gallinero, December 2010. Photo by Zuloark.

(terra)formations of impatience and capability, for eclectic and wilding investigations into and out from the material depths of precarity. These manifold projects - which include community projects in open-source architecture, so-called do-it-with-others educational platforms, or copyleft social squat centers-speak about a city that accrues and proliferates through various languages, media, and interfaces of description; through archives, archaeologies, and technologies that deposit but also help visualize and trace its memories and hopes; and through systems of apprenticeships, guesswork, and assay that exfoliate its various nervous systems. I aim in this article to provide some glimpses into how auto-construction has surfaced and circulated as a habitus and a habitat - an infrastructure and a sensory organ - for an experience of living-with and -along in Madrid.

As I use it here, the concept of auto-construction undergoes an important conceptual migration: from its original use in designating self-help housing in the global South (auto-construction as object), to more recent usages signaling the inventiveness and resourcefulness of self-organized initiatives (auto-construction as process), to my own proposal for thinking of auto-construction as a method and platform of inquiry and exploration. In justifying such a transition, I set up a conversation with the comparative literature on urban auto-construction. This 
is a risky strategy, I am aware. The literature on auto-construction in the global South is often a far cry from the community projects in political autonomy and democratic experimentation that I report on. There is a vast expanse between the cultural geographies and political economies of the peripheries of the urban South and Madrid's own vectors of peripheralization. Yet I believe the comparison is one worth pursuing because of what it can teach us about the status of the ethnographic method today, in particular about the consequences of its co-inhabiting, along with other methods, complex worlds of partial and interdependent descriptions. The literature on auto-construction has proven exquisitely attentive to the insightful and resourceful ways through which people furnish environments of desire and anticipation, action and existence for themselves. In this sense, it has equipped us with a certain sensibility for unpacking how people's urban navigations function simultaneously as methods for questioning and experimenting, opening up new vistas on how the city auto-constructs its own theoretical worlds.

This interest in the mutual and recursive auto-construction of the city and theory is my central proposition. I am interested in the purchase of auto-construction as a material metaphor for rendering visible how theory itself is autoconstructed. In this context, I want to bring some recent reflections on theory design around methods of invention (Lury and Wakeford 2012), prototyping (Corsín Jiménez 2014b), and experiments in collaborative concept work (Marcus 2014) to bear on some longstanding debates about the nature of the urban question-as well as to ask some broader questions regarding the methodological venues and resources of anthropological discovery.

Despite some noteworthy and innovative proposals for making explicit "the strange language of urbanization” (Boucher et al. 2008), the fact remains that most recent urban theory has done little to explicate its own moments of articulation. The nature of the empirical remains mostly unproblematized, and it is only the adequateness of this or that body of theory that has been highlighted for discussion. Thus, to this day, investigations into how the urban is rendered visible as method and field site remain conspicuously absent from the literature. The relation between the field as empirical site and the field as theoretical project remains largely bracketed and unexplored. We have come to naturalize scholarly accounts as speaking about a place (geographical or epistemic), paying little or no attention to how such places must themselves be drawn together as empirical and pragmatic problems. The empirical problems of this or that place cover up the very operation of problematization as method. 
My proposal for using auto-construction as a heuristic centers on the concept's specific (recursive) twinning of method and theory. Auto-construction offers an image for understanding how empirical problems are auto-constructed into situated theories and theoretical navigations. More often than not, these theoretical designs are premised on a dynamic and collaborative accompaniment of inquiry that enlists local communities and researchers, multiple media and mediators, working with and across a variety of genres and aesthetics of description (Rabinow 2011). Such pragmatic and inventive exercises in design and construction also render visible the nature of the city as a problem of method. That is, the city is a method — of designs, problematizations, and theories - in constant auto-construction. ${ }^{3}$

\section{AUTO-DAZZLE}

The story of Don Antonio is one I must have heard told dozens of times over the past three years. Don Antonio has his ways. Now in his seventies and retired, he wakes up early in the morning and enjoys opening the doors of his balcony, which he leaves open for the remains of the day. The soundscapes and breezes of the city call on his parlor, bringing along the gaiety and liveliness of a downtown location in Madrid's historic quarter. There are the sounds of motorbikes roaring past, of children shouting, of the bulky maneuvering of trucks offloading their cargo just opposite Don Antonio's building, at the popular market of La Cebada. Occasionally the rhythms and intonations of a musical performance or a theatrical play make their way into Don Antonio's living room. In such cases, however, if the volume is too high, Don Antonio picks up his mobile phone and calls Manuel, who will gently ask the actors or the sound mixers to quiet down their performance.

This is a story I have heard Manuel tell time and time again. Manuel is a member of the guerrilla architectural collective Zuloark, which was first involved, alongside local neighborhood associations, artists, activists, shopkeepers, and schools, in the transformation of a derelict and vacant open-air site in the heart of the La Latina neighborhood into a self-managed community project. We shall be hearing more about the story of this community space, locally known as El Campo de Cebada, shortly.

The story of Don Antonio is one that Manuel has recounted in front of multiple and variegated audiences. I have witnessed him dramatize the story before hundreds of people in an architectural salon at Madrid's Guild of Architects. I have also seen him deliver wonderfully colorful versions of the anecdote 


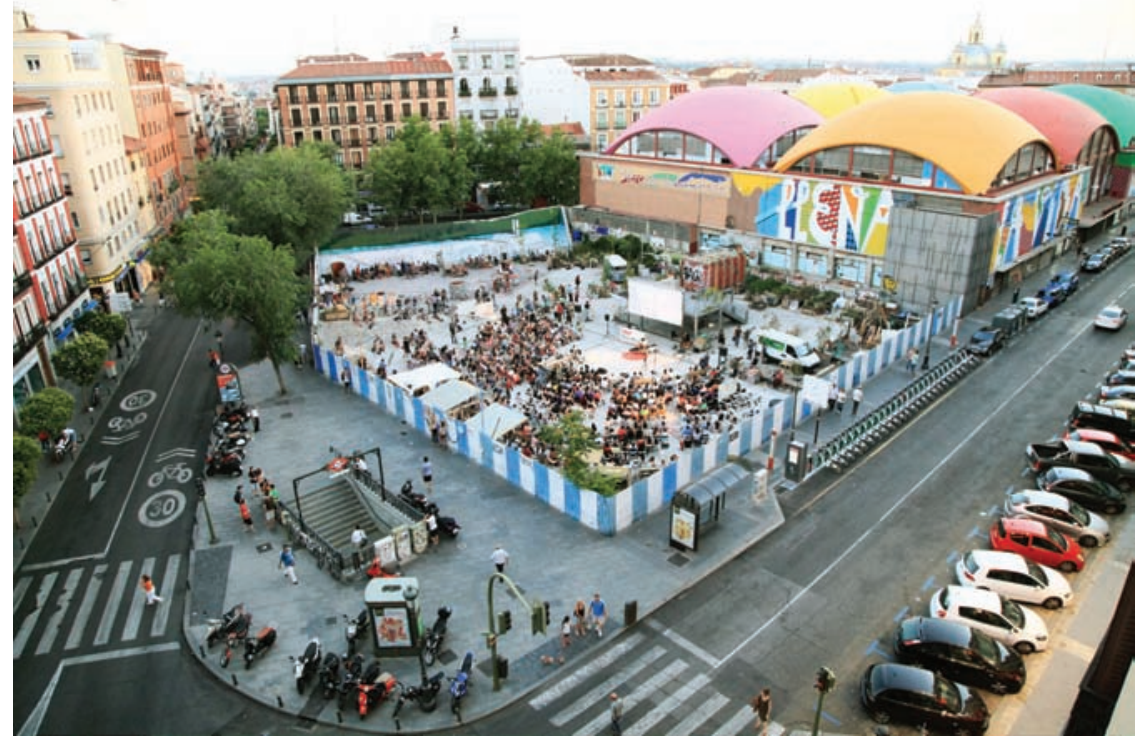

Figure 3. TEDx MadridSalon at El Campo de Cebada, July 2014. Photo by Zuloark.

at various meetings with municipal delegates and policymakers. I have seen him rehearse an impassioned and charismatic version at a meeting of activists at a social squat center, and produce slightly different variants for talks at cultural centers and museums. He has also retold the story on camera for a video documentary, and of course he has staged endless similar performances for friends and colleagues. The story also exists in print, in texts that Zuloark has written for architectural journals and magazines, as well as design portfolios the collective has submitted to industry prizes and awards.

For Manuel, the story of Don Antonio exemplifies how grassroots community projects must continuously adjust and reproblematize the designs of method. In the case of El Campo de Cebada, it shows in the collective's design of an ecology of practices that attends to the interests and concerns of neighboring residents, including Don Antonio's particular sensibility toward the acoustics of the vicinity. Members of El Campo will often say that theirs is an approach that habita la controversia, that does not shy away from dwelling in controversy, and which calls, correspondingly, for designing habitats for each and every problem. In this light, the story of Don Antonio rehearses many of the narratives and tropes that have become common ploys in the classic literature on auto-construction: about the inventiveness, resilience, and resourcefulness of urban relations; their ability to operate under the radar of standardized market or state practices by 
sounding out horizons of mutual feeling and complicity, circuits of give-and-take that consolidate — sometimes erratically, sometimes fleetingly, yet sometimes sustainably too-spaces of convergence and productivity.

Yet I trust that there is another, complementary transcript to Don Antonio's story. As noted, the story has circulated widely, in a variety of media forms, registers, and venues, as a story about methods, about the auto-construction of these methods, as well as the method of auto-construction more broadly. Moreover, this story is only one of many other stories and anecdotes told about emerging experiments in auto-construction elsewhere in the city (such as the Autobarrios project with which I opened this article). Therefore, in print and in auditoriums, in public oratory and private talk, these stories seem to function as both vehicles and anchors for an infrastructure of feeling for the city. The circulation of auto-construction as story, as metaphor, and as method surfaces as a distinctive and consequential economy and repertoire of urban skills, senses, and sensibilities. Borrowing a term from AbdouMaliq Simone (2006, 359), we may say that auto-construction is slowly, gradually, taking shape as a "perceptual system" for the city, a sensory organ that functions as at once an economy of attention and an economy of resources, and that finds tentative anchorage in the city as a method for other methods.

Yet if auto-construction works as a method for other methods in the city, where does that leave ethnography? What does an ethnographic effect look like amid such a dense panoply of methodological effects? Does ethnography itself get to be auto-constructed?

These are important questions that go to the heart of the anthropological project. As noted above, they point to the difficulties that haunt the design of ethnography as a field of inquiry: how do we construct our methods side by side with other people's construction of their own methods? Are not our methods (ours and theirs) auto-constructed through each other?

The literature on urban auto-construction provides an especially poignant place for exploring these issues because, as noted above, it has traditionally been framed as a reservoir of cultural ingenuity and resilience. Auto-construction has provided scholars with an apparently natural metaphor for sociocultural creativity, thence justifying subsequent claims to analytical and epistemic innovation. There is a wonderful passage in Marilyn Strathern's $(1999,6)$ well-known reflection on "the ethnographic moment" that captures this slippage beautifully, noting how our capacity for ethnographic description is often preempted by our (Euro-American) expectations concerning what counts as an epistemic effect in the first place. 
One "could refer to it as auto-dazzle," Strathern (1999, 20) says: "Knowledge involves creativity, effort, production; it loves to uncover creativity, effort, production!" Scholars are intent on staging the products of research in terms of "discovery and re-discovery," where our capacity to reveal something mirrors the "revelatory practices" that we encounter in the field itself (Strathern 1999, 20). Put somewhat differently, we might say that the care with which we construct our ethnographic descriptions aims at dazzling (surprising, confusing, mystifying) our readers in terms symmetrical to how that moment of dazzle took hold of us and our informants in the ethnographic encounter. Yet this symmetry is itself problematic and should not be taken at face value, for otherwise we risk falling in love, as Strathern puts it, with our own anticipations of consequence. We risk auto-constructing dazzle as an epistemic effect by auto-dazzling how the ethnography and the analysis construct each other.

\section{AUTO-CONSTRUCTION}

In his now classic Cultural Anthropology article on auto-construction, ${ }^{4}$ James Holston (1991) introduced the concept as a heuristic for thinking about the complex dynamics that subtend processes of peripheral urbanization in Brazil. These processes, he noted, are at once capitalist- and state-driven, for through the process of building their homes, the inhabitants of peripheral and informal communities self-fashion a seemingly paradoxical type of political subjectivity for themselves as at once rights holders and consumer citizens: house building becomes for them an arena for the contestation and struggle over entitlements and rights to home ownership (and the matrix of public services and infrastructures wherein these are located, such as water sanitation, sewage, etc.). It also becomes a template for drawing on and expressing a wide array of consumer desires and aesthetics, for example, in matters of interior decoration or material culture. The vitality of auto-construction - the desideratum that the house incarnates as a life project, the vibrancy and energetics of family and community commitments that underwrite it, the space of political urgency and fundamental needs that it indexes - bulges onto the political landscape of the modernist city, which otherwise crumbles and falls to pieces in the background. Self-built and auto-constructed, the city-yet-to-come advances, encroaching on, if not wholly in defiance of, the fatuous landscapes of modernity. The destruction and the auto-construction of the city as theory: few concepts can say so much with so little.

While originally deployed to describe a specific modality of housing projects in developing countries (e.g., Arecchi 1984; Banck 1986), auto-construction has 
today become very much a staple of urban theory. From do-it-yourself urban designs to self-help housing, from community architectural projects to opensource urban infrastructures, from the right to the city to the right to infrastructure, auto-construction has become a sine qua non of the descriptive repertoire and analytical vocabulary of the informal city, if not its most promissory and fertile conceptual reservoir (e.g., Iveson 2013; McGuirk 2014; Eizenberg 2012; Purcell 2013; Corsín Jiménez 2014a). Under one guise or another, the literature on auto-construction has borne witness to the birth and rebirth of the city, time and again: as a source of vitality and improvisation; of skill, craft, and tacit knowledge; of political acuity and community values; of autonomy and resistance; of resilience and resourcefulness; of perseverance, defiance, and irreducibility. Auto-construction and its proxies have been used to map and trace manifold topologies of epistemic overflow, where technical, environmental, and political relations fly below the radar of market and state practices, or generate unsuspected and yet productive displacements and reconfigurations between them. They have provided a conceptual sensibility for framing the messy entanglements of material energies, affective relations, political capacities, and social creativity that make up city life.

There is a specific geopolitical history, however, to our contemporary state of enamorment with the informal, the energetic, and the auto-constructed. In a recent and important piece on "slum as theory," Vyjayanthi Rao (2006) has taken issue with some of the epistemological assumptions subtending how we have come to grasp the urban condition. "What," she asks, "counts as knowledge of the urban?" (Rao 2006, 225). She lays out her argument through a critical engagement with Mike Davis's (2004) well-known essay on the planetary urbanism of slums (see also Davis 2006). Davis's work has been criticized for presenting an apocalyptic and dystopian vision of urban development, where the reality of empire, global capital, and neoliberalism condemn a "surplus humanity," in Davis's (2006, 174-98) creepy formulation, to a future of misery, disease, crime, and desperation. Apropos of auto-construction, Davis (2006, 70-94) dedicates one chapter of his book Planet of Slums to criticizing what he calls the "illusions of self-help" that informed the World Bank's philosophical and programmatic approach to housing policies starting in the 1970s. He traces the World Bank's vision to the ideas of the English anarchist architect John Turner who, after living in the squatter settlements of Lima from 1957 to 1965, developed an understanding of community self-organization and autonomy that led to various writings and proposals defending self-building as a policy alternative-so-called sites and services pro- 
grams designed to provide land and basic infrastructural services that people would occupy to develop their own housing projects (Turner and Fichter 1972; Turner 1976). Yet while, for Davis (2006, 72), this "amalgam of anarchism and neoliberalism" did little but legitimate the state's retreat as a provider of public services and infrastructure, Turner's work has otherwise been recuperated as a precursor to a type of activist architecture born out of the experience of Latin American informality that may hold global lessons for all: "If there is one area where Latin American experience contains a global lesson . . . it is its attitude to the informal city. What do we mean by 'informal'? The short answer is slums . . . [which] are far from chaotic. They may lack essential services, yet they operate under their own self-regulating systems" (McGuirk 2014, 25).

The Latin American slum thus stands as a metonym of entrepreneurial pragmatism - optimist, extrovert, hands-on_ operating as an epistemic space: "active forms: systems, networks, connections, infrastructure - all of these are more important arguably than the dumb object-housing of the modernists" (McGuirk 2014, 33). Indeed, what draws Rao herself to the debate is the way in which Davis deploys the slum as a theoretical construct whose geographical and historical axes rest "upon the 'city of the South' as its proxy subject. A new understanding of the global emerges by situating the spaces of these cities at the epicentre of a certain catastrophic appetite of global capital flows and turning those spaces into a new territorial principle of order" (Rao 2006, 227). In its place, Rao (2006, 232) offers an alternative theoretical figuration for the slum, where rather than a proxy for locating the pressure zones of empire and capital, the "slum becomes an epistemological shorthand for tracking the cracks . . . and for locating the mutations of the modern state."

Slum as theory, slum as pragmatism: from the slum as an aftershock of capital to the slum as the auto-dazzle of theory?

\section{AUTO-PERIPHERIES}

The 2008 financial crisis pushed the Spanish economy into the darkest corners of the European periphery. By 2011, the meltdown of the property market had dragged the urban middle and working classes into an abyss of precariousness and desperation. Between 2006 and 2010, income inequality increased in Spain more than in any other developed economy (ILO 2015, 23), with the top 20 percent of society 7.5 times richer than the bottom fifth (Cáritas 2013, 3). In 2011, unemployment hit 21.4 percent of the working population, or 5 million people, rising to 42.3 percent in the case of workers under twenty-five. ${ }^{5}$ While 
between 2007 and 2011 the incomes of the poorest 10 percent had dropped by 13 percent per year, this amounted to less than 1.5 percent for the richest 10 percent (OECD 2015, 24). As the right-wing Partido Popular government set the benchmark for austerity policies, the poverty rate doubled to 18 percent, "with young people replacing the elderly as the group most at risk of poverty" (OECD 2015, 25).

On May 15, 2011, following a public demonstration over the political management of the economic crisis, a group of protesters set up an encampment at Madrid's Puerta del Sol, the city's historic central square, that in a matter of days grew into a complex infrastructure and social movement, in due time transforming the nature of municipal politics in the city. The image of the encampmentrugged, provisional, auto-constructed - circulated around the globe and became an emblem of the Spanish indignados movement (see figures 4 and 5). The encampment organized itself into a "city in miniature," as people rejoiced in saying. It provided temporary food and shelter for campers; there was a kitchen and a refectory, a nursery, a library, as well as an open-source infrastructure of solar panels and wireless networks. Protesters came together in a variety of assemblies and working groups, on matters such as long-term politics or feminism, a respect and care commission, and a task force dedicated to curating and preserving the movement's archives. Methodologies popped up everywhere-for assembling, for mediating conflicts, for cultivating the hospitality of strangers (Corsín Jiménez and Estalella 2014).

Having taken up residence at the very geographical and political heart of the Spanish state, from day one the encampment faced up to its eventual dismantling and worked toward its future reappearance in more than a hundred popular assemblies across Madrid's neighborhoods. Therefore, when the encampment finally came down, a month into the inaugural occupation, it was the energy of this auto-peripheralization - a proliferation of assemblies, centros sociales autogestionados (self-managed social centers), urban community orchards, and commons networks across the city's hinterland (Walliser 2013) — that took over and kept the momentum. The peripheries took center stage and resumed the work of nurturing the capacity for-self-peripheralization.

In her recent writings on subaltern urbanism, Ananya Roy $(2011,227,231)$ has suggested that social theory may be at risk of fetishizing the slum as an epistemic and topological vector, noting how the metonym of the slum has become a conceptual reservoir from which to justify speaking of both "self-organizing economies of entrepreneurialism" and the "habitus of the dispossessed." The slum, 


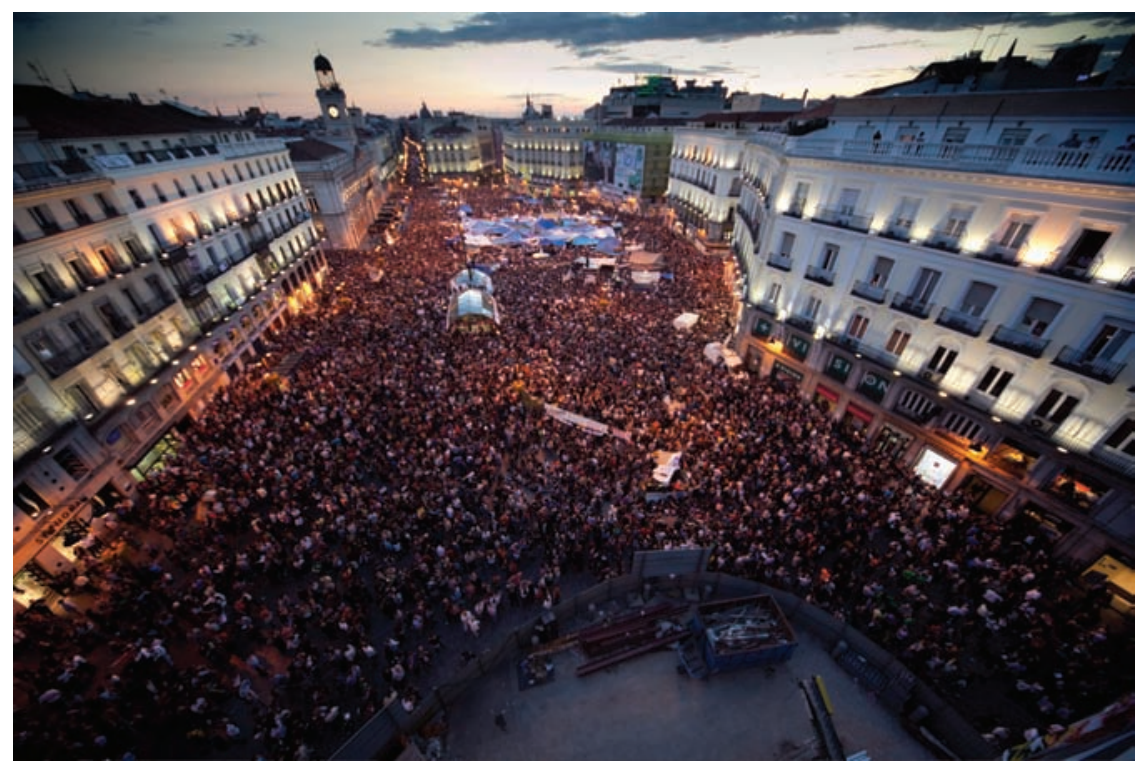

Figure 4. Occupation Puerta del Sol, May 2011. Photo by Julio Albarrán.

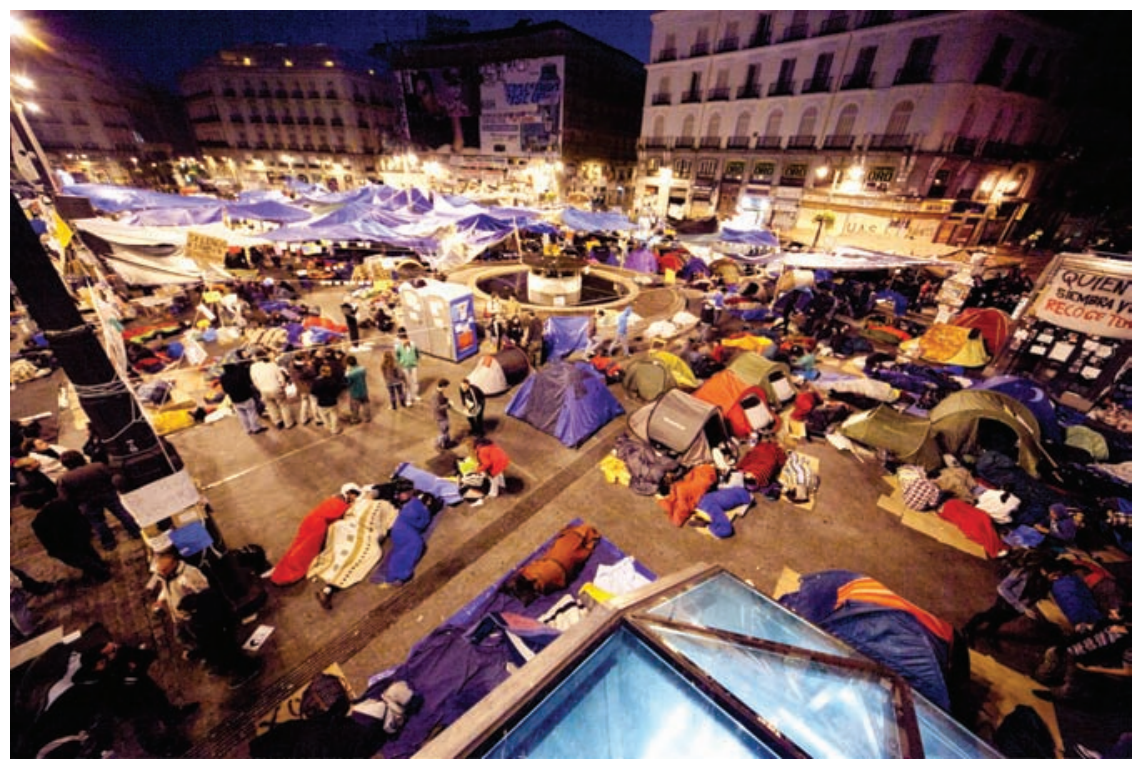

Figure 5. Acampada Sol, May 2011. Photo by Julio Albarrán

as Roy rightly observes, has become a dazzle for theory, which is why she calls for developing a more nuanced and subtle heuristics of subalternity, which, for her, includes an appeal to thinking with and across the zones of exception, gray 
spaces, and processes of urban informality inhabiting the interstices of the territorial, juridical, and legal/lethal regimes of capital and state sovereignty. One other such notion is the periphery, which, following AbdouMaliq Simone (2010), Roy $(2011$, 232) defines as both "a space in the making and a form of making theory."

I am taken by Roy's $(2011,224)$ “intervention in the epistemologies and methodologies of urban studies." Her outlining of the metonymic cul-de-sacs that slum urbanism has got us into is most pertinent and valuable. But let me pause for a moment with her focus on the periphery as heuristic. In the double sense that Roy attributes to the term - that is, as designating both a geographic and an epistemic space - I take it that the promise the periphery might hold for description lies in the fact that the two spaces (the geographic and the epistemic) do not, in fact, wholly coincide. The periphery, as I see it, is what holds both descriptive spaces together and, simultaneously, apart. The periphery works as a descriptive and epistemic figure insofar as it can keep the tension in place - such that one can imagine, for instance, what the work of auto-peripheralization might entail. ${ }^{6}$ For this reason, I believe it is important to be able to specify under which conditions the periphery as a genre of description can describe the periphery as urban process: how does the operation of problematization for which the periphery stands as method inhabit its field site? What work goes into the auto-construction of the periphery (by scholars and residents) as a method of theory for the city?

These are questions, I would like to insist, that go to the heart of how ethnography takes up residence in a field site - how it draws itself together as an inventive and pragmatic design, how it auto-constructs itself, and therefore how it relates to other methods of auto-construction and exploration. Let me be more specific.

In her deployment of the term as a double heuristic (now geographical territory, now concept), Roy recalls the work of James Holston and Teresa Caldeira (2008, 21), who make use of the ethnographic category periferia (periphery) to describe the "settlements of people beyond a city center's perimeter of urbanized and legalized services" characteristic of Brazilian urbanization. As noted above, the periphery does not signal a stable territorial demarcation but a shifting geo-epistemic operator: it is a dynamic vector that indexes the

relations of mutual dependence-a social production and circulation of space - in which centers and peripheries each define the other through an 
apparatus of domination . . comprising political, legal, social, economic and infrastructural components whose interrelations constantly change. As a result, peripheries as both place and concept shift in location and meaning through time. (Holston and Caldeira 2008, 21; emphasis added)

Holston and Caldeira $(2008,21)$ go on to show how urban experiences of peripheries sparked a variety of neighborhood-based social movements and grassroots mobilizations, whose claims and demands helped "mark a decisive moment in the constitution of a new conception of citizenship" in the history of Brazil. Although the processes through which such experiences of what they call insurgent citizenship came to the fore were many and complex, the claims that residents have made to the city over time have often been specifically grounded in and through the experience of auto-construction: "Insurgent citizenship depends," Holston and Caldeira (2008, 22) tell us, "on a sense of self-worth undeniably connected to property ownership and the autoconstruction of houses." Autoconstruction thus provides a material and volitional locus for the self-expression of the city as an affective and political desideratum.

In his earlier work on auto-construction, however, Holston (1991, 456) goes even further in specifying the "aesthetics of autoconstruction" animating and styling such expressions of self-worth. According to Holston, the question of aesthetics proves central to understanding the personal investments and challenges that people mobilize when projecting their houses as outward manifestations of their selves and markers of their relations to others. As he puts it, houses are “'good to think' because they channel personal experience into a public idiom, architecture. . . . This idiom is a visual calculus of appearances - a particular style of facade, certain decorations, the display of appliances, a specific finish or material, and so forth - widely intelligible as symbolic notations about self and society, present and future" (Holston 1991, 456). A crucial dimension of this visual calculus, he observes, relates to the repertoire of aesthetic designs and styles that people draw from to achieve "an intended effect" (Holston 1991, 460). The goal is to bring to fruition a sense of innovation, to showcase one's mastery of an idiom that will justify general approbation and the recognition that one's house has "personality" (Holston 1991, 460). One is almost tempted to say that such designs are aimed at dazzling one's neighbors.

Yet if dazzle is much sought after, no little amount of effort goes into controlling the effects of auto-dazzle as well. As Holston notes, it is of utmost 
importance to avoid imitation and, above everything else, to deflect any hint of suspicion that one may have been copying:

People usually refuse, to the point of real irritation, to admit that they derive their house designs or decorations from any source other than pure inspiration. Yet, I have seen them exchanging house plans, perusing fashion and home-life magazines, taking field trips to shopping centers and elite neighborhoods, and making careful observations about the upper-class habits and décor presented in TV soap operas. Moreover, they have to use the same construction materials and household goods to make meaningful statements in the sign system of autoconstruction. The problem is that they must, and do, avidly copy. (Holston 1991, 461)

This is why, as Holston $(1991,461)$ underscores, "to question their sources is to tarnish their sense of personal distinction in which they have so heavily invested." This is not therefore simply a question about what auto-construction accomplishes or what it stands for. It is not a question about auto-construction as object (housing) or auto-construction as process (self-help, self-organization). Rather, what we see here is how the city advances surreptitiously, as it simultaneously gropes and touts its way through waves of informality and trickery, of seduction and allure, glamor and imitation, production and predation. The city auto-constructs itself as a complex economy of urges and aspirations, a contradictory hide-andseek of lure and abandonment, desire and affectation that impedes any definitive formalization of what the periphery does to the city or how it works. The city fares here as "a kind of perceptual system, a way of seeing" (Simone 2006, 359): an evanescent landscape whose outlines - the tricks and trades of mimesis and camouflage, of splendor or deception - one must constantly learn to see. We may think of auto-construction, therefore, as a sort of auto-heuristics for the city, a device that can help us adumbrate, but also inhabit, the tensions and elisions that we all inevitably encounter between the city's moments of dazzle and our moments of auto-dazzle with the city. Auto-construction as method.

\section{AUTO-HEURISTICS}

Residents of the La Latina neighborhood remember the date of May 15, 2011 (the date of Puerta del Sol's occupation) for a different, if related reason. On that day, a group of neighbors, community activists, and artists took to the streets to occupy three thousand square meters of land that had been lying vacant 
ever since plans for a sports complex were brought to a halt in the aftermath of the economic crisis.

The reasons for the occupation were celebratory. The neighbors had been granted the management of the space after eight months of negotiations with the Departments of Citizen Participation and Inland Revenue and with their local borough representatives from the municipal government. The residents had proven swift and perspicacious organizers. Back in September 2010, the government had authorized a makeshift occupation in the context of a weekend cultural festival - the White Night curated by Basurama. With the event over, and the site locked up and abandoned again, some neighbors "found" a copy of the key to the gates fencing in the space.

The festival had proven a success, and it took little imagination for the neighbors to realize the formidable community potential of the vacant lot. They organized an asamblea (assembly) that soon entered into negotiations and concerted action with a variety of neighborhood stakeholders, including the two local neighborhood associations, local schools and shopkeepers, nearby squat social centers, and a variety of artistic and countercultural collectives. Impressed by the agility of the mobilization, and at any rate with no alternative plans for the site, the municipality agreed to an acuerdo de cesión temporal (temporary management permit) for the space.

It was an opportunity not to be missed. The neighbors moved swiftly, in a variety of registers and media. They set up an email distribution list, a Twitter account, and a Facebook page. They experimented with a variety of organizational formats - a Neighborhood Assembly, a Commission for Economic Affairs, and an Operations Commission - as well as a self-branded (if short-lived) hybrid governance structure that included representatives from the municipal government and delegates from the Neighborhood Assembly.

Within weeks the space acquired strange urban properties: this was a plaza, three thousand square meters in the heart of Madrid's old town no less, that had suddenly become an espacio público de gestión ciudadana, a public space managed by citizens. The space had been salvaged by the neighbors, and displayed proudly the ruggedness and urgency of its salvage methodologies. I do not mean this derisively. On the contrary: El Campo boasts wooden planks and construction materials used by guerrilla architectural collectives in urbanism workshops. Passers-by, architecture students, and local neighbors have imagined, designed, and made unorthodox pieces of urban equipment later used in community gardening, in book fairs and organic food markets, in theatrical productions by local schools 
and political rallies by slumbering anarchist formations. El Campo stores paints, brushes, chairs, plastics, and urban waste with which children have improvised playgrounds and battle scenes on its patio, with which scenographers have traced the outlines of impossibly allegorical cities, and amid whose forensic archaeologies teenage lovers have sought refuge from the violent transparency of the society of control. Salvage methodologies have "liberated the space" (liberar el espacio), as neighbors proudly observed, and turned it into something at once more and less than public space.

On any Sunday morning, coinciding with a flea market next door, hundreds of thousands of people may walk past or into El Campo. The atmosphere is festive and joyous, libidinous and reminiscent of a bazaar, an exuberant public space. But it is also less than a public space, for the state is disappeared, an auctoritas in absentia. As a result, El Campo has taxed the patience, resourcefulness, and intellectual powers of its citizen-managers. The scarcely twenty people who assiduously turn up at the weekly assembly meetings are overwhelmed and overworked. The daily chores of maintenance (opening the gates, dusting and arranging the space, kicking people out when closing time approaches), going through email correspondence, and keeping a lively digital community presencefor these chores, there never seem to be enough people. On some occasions the space has remained closed, for no key-holders were around to open its gate. Events have had to be postponed or cancelled, people have become angry, and discussions have flared at the assembly, which in turn has seen members leave,

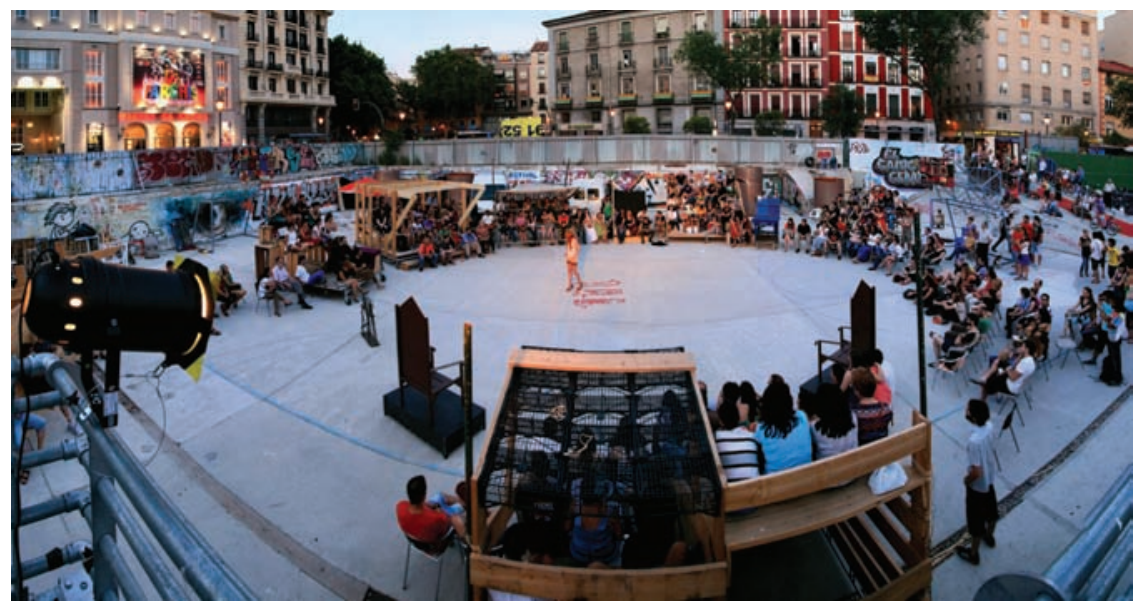

Figure 6. Theatrical performance at El Campo de Cebada, July 2012. Photo by Zuloark. 
as well as new ones arrive. Three thousand square meters of open-air space can take anyone's breath away.

That El Campo has somewhat failed as a representational space, as a space of political participation and autonomy, has not prevented it from working in many other ways, for it remains a venue where things happen. While it is, perhaps, incapable of centering itself as an urban locale, of finding a language for itself as an urban form, El Campo has otherwise succeeded in providing a platform for an "intensive urbanization of outlook," city's self-peripheralization.

For example, El Campo has hosted numerous debates and forums about the role of the academy and its relationship to the city, including the organization of a Popular University now in its third year. One of the most interesting projects in this respect has been the educational collective \#edumeet. The initiative first met at El Campo in September 2011, following a Twitter exchange over matters of education and the city. The meeting brought together a group of some twenty people, including some of the original community activists and architects who had occupied the site some months earlier, as well as newcomers to El Campo, such as teachers, designers, and information technology consultants. The group convened thereafter every second Thursday evening, in meetings organized via Twitter, although without any expectation of attendance.

The conversations at \#edumeet gravitated toward a concern with the nature of learning in the modern city, and in particular with the conditions - the built environment, the rhythms of capital, the social and technical forms of experience - that enabled or discouraged the awakening of the city's pedagogical capacities and affordances (see figure 7). People would often express concern with the fragility of a meeting that took place after hours, in the open air, not infrequently perambulating the nightly hospitality of bars or squat centers. It was a strange hospitality for which the meetings seemed to be groping. Yet it was also this transience and urban wildness that people most treasured, as they navigated and sounded out the landscapes, the penumbras and the promises of shared learning. At the meetings, attendees voiced their dissatisfaction with formal education, not least with the role that the university played in the standardization and slumbering of urban experience. There was considerable discussion, for instance, about the kind of stance that research takes when it comes to the city: What does it mean to investigate the city? What types of relationships and bodies do the action of research elicit vis-à-vis the aesthetic inscriptions of artists, the nurturing accompaniments of teachers, or the literary curiosity of journalists? How does re- 
search take residence in the urban fabric, what sorts of traces does it leave, and what memories and awakenings does it excite? Some people would occasionally turn to me in my role as ethnographer with these and similar questions, curious to understand how ethnography shapes itself into a presence in the city, how it constructs a space of inquiry amid the vicissitudes and turmoil of a world in crisis. Where and how, they wanted to know, did ethnography fit into this budding, yet precarious infrastructure of feeling?

These were pressing questions for many participants, some of whom felt compelled to leave testimony, to "make visible" (hacer visible) that these discussions were being had, that they were taking place: indeed, that there were specific places in the city for them, or at least specific arrangements and possibilities. For instance, it became an established practice for attendees to report the discussions live on Twitter, embedding drawings and photographs of the group, excerpts from notes, images from the surrounding environment, and the like. Attendees would also write up the evening's discussions in blog posts or produce summaries for online architectural and urbanist forums; some would even venture theoretical forays into the discursive realms of so-called peer-to-peer and do-it-yourself urbanism. These arrangements signaled specific distributions of presence and action, of bodies-in-place and bodies-across-space; directions to and swells of movement, excitement, expectation, and reward. They deployed summative systems and methods for intuiting and tracking, for knowing and acknowledging, for witnessing and learning. "The city," people would hiss to each other with sparkling eyes, "surges."

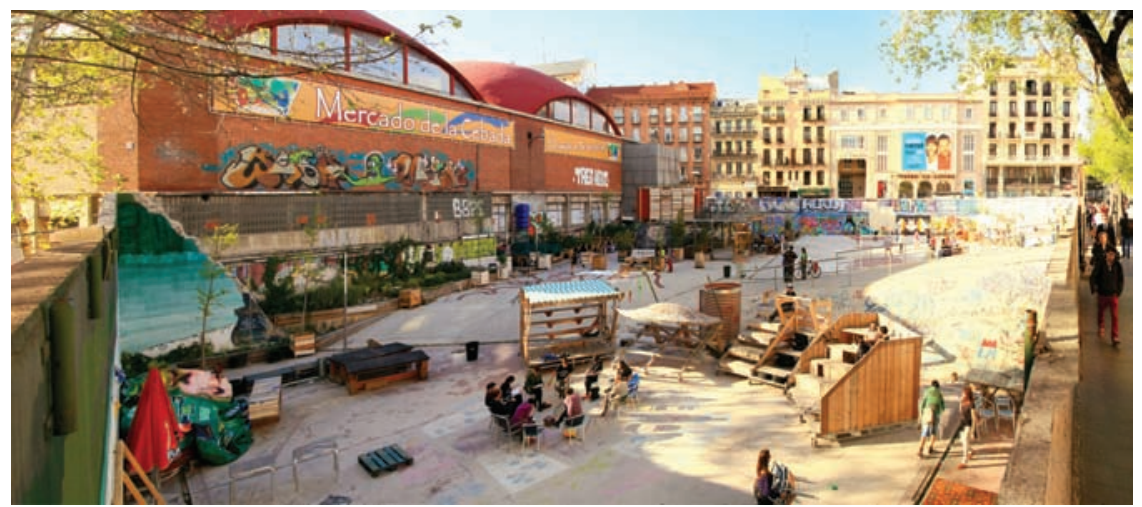

Figure 7. El Campo de Cebada, May 2013. Photo by Zuloark. 
As time went by, \#edumeet became a reference for discussions on free culture and the city. By 2012, Arquitectura Viva, Spain's most prestigious architectural journal, published a special issue on emerging architectural collectives that included an entry on \#edumeet. The entry was self-curated by \#edumeet's Twitter followers and read thus:

\#edumeet / learning ambiances, autonomous and temporal / people that talk about education at la Cebada every second Thursday / or in bars / . . . affective space around learning / . . . a \#hashtag that belongs to no one / may well be happening right now without us knowing about it / . . . un-learning by meeting new people who do not share your interests / every new tweet is a new rendering of \#edumeet. (edumeet 2012, 26; author's translation)

There is another sense in which witnessing and learning became important operators in the organization of experience at El Campo. Ever since the space was liberated in February 2011, Basurama and Zuloark have been organizing socalled handmade urbanism workshops at the site, where students of architecture, passers-by, and neighbors are invited to design and construct pieces of urbanism for the city (see figure 8). As the architects like to say, "today urbanism is bricourbanism, a handmade job [el urbanismo es brico-urbanismo, se hace con las manos]." A central pedagogical dimension of these workshops is that all designs are documented following what the architects describe as an "open-source philosophy." This requires participants to make not just technical notes and instructional diagrams for every object or installation, but also explanations regarding the types of materials used, their affordances, how and where they are sourced, and the like. The documentation includes photographs, diagrams, videos, or 3-D renderings, which are then uploaded and made available online, in the hope that they will become methods or "prototypes," as members of Zuloark like to put it, for the ongoing investigation of the city as an open-source environment. Some of these prototypes will travel to other parts of the city, such as when the prototype for an urban bench is disassembled and later used in the construction of community-garden beds or used for furnishing a local school's playground in autoconstruction workshops with students. The travels of these various objects and resources entangle the city in a thick texture of social and material relations, which people have started to speak of as metodologías para hacer ciudad, methods for eliciting the city's capacities. 


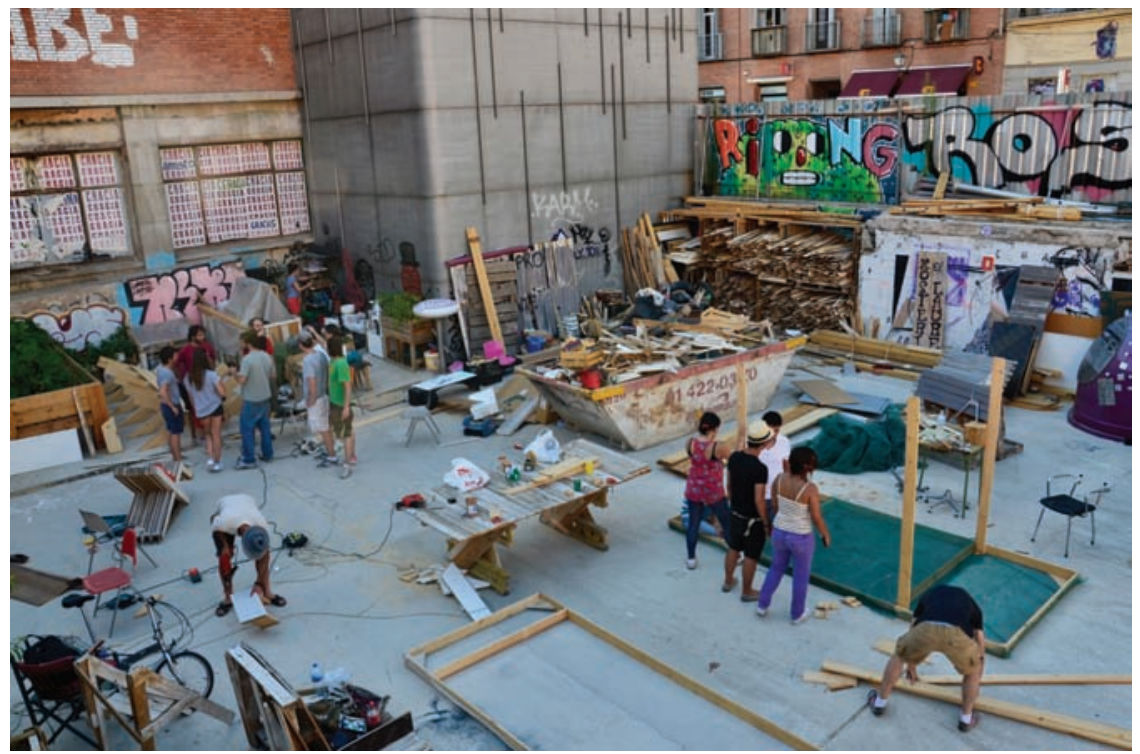

Figure 8. Handmade urbanism workshop at El Campo de Cebada, July 2012. Photo by Alberto Corsín Jiménez.

However, the documentation that participants produce at the workshops is erratic and inconsistent. Some relish the opportunity to document exhaustively their work, and might even carry out interviews with local neighbors in an attempt to substantiate a design or aesthetic choice, while others get away with little more than a couple of photographs or drawings. Such unevenness has troubled the architectural collectives. I have had long conversations with Manuel regarding the urbanness of these designs and objects, given that one can hardly speak of them as having standards of any kind. On one occasion, Manuel probed deeper than previously on the specific inflection that open-source designs brought to the relationship between knowledge and acknowledgment, between learning and witnessing in urban affairs: "The thing is," he said, "that when the municipality speaks of 'participatory design,' they are thinking how to embed representative voices into infrastructures and standards, say, for designing children's playgrounds or urban equipment for plazas and parks. We, on the other hand, are thinking of pedagogy and learning: how to design spaces and infrastructures so that communities can learn from one another." He continued: "So when we say that El Campo is una infraestructura para la ciudad, an infrastructure for the city, we don't just mean to say that it provides the space or materials for the community to carry out activities that were previously unimaginable. Rather, it is the learning 
processes that it enables and sets in circulation that we are interested in. It is the circulating economy of learning that is the infrastructure: the auto-construction of the city as an infrastructure of apprenticeships." Aurora, another member of Zuloark, chipped in: "Everywhere you look, from urban community gardens to \#edumeet or the 15M neighborhood assemblies, there is an explicit effervescence and consciousness regarding the apprenticeships that the city is deploying [los aprendizajes que se despliegan por la ciudad]." But, she added, "one also senses that much of it passes unnoticed, that we have no place from where to make all those learning processes learnable: what does it mean to make an urban apprenticeship legible? What kind of learning is the city?" (cf. McFarlane 2011). ${ }^{8}$

\section{CONCLUSION}

Auto-construction has a long tradition in urban studies and anthropology. By 1984, Alberto Arecchi had pointed out the significance of auto-construction as an empirical system of problem-solving in African cities, although he likewise alerted readers to the risks of invoking auto-construction as a romanticized, neocolonial trope for indigenous self-empowerment: "Where auto-construction is a traditional symptom of poverty, where new governments are anxious to modernize, to make slums and huts a thing of the past, one sometimes risks sounding neo-colonialist when propounding the advantages of auto-construction" (Arecchi 1984, 575-76). The allure and the perils of auto-construction have remained with urban theory ever since. The metonym of the slum, in Ananya Roy's description, remains a powerful placeholder for both dystopian and inventive accounts of the urban: for the retrograde, the resilient, and the resourceful.

Inspired by recent scholarship that seeks in the periphery, the informal, and the subaltern new perceptual systems for thinking (with) the city, in this article I have offered an argument for the use of auto-construction as a double heuristic of method and theory for the urban condition. "Rather than the city being somehow read through particular schemes of power," Morten Nielsen $(2011,352)$ has written in his study of auto-construction in Maputo, Mozambique, the lens of inverse governmentality (as he cleverly describes such self-help housing projects) offers a perspective in which "the city consequently reads itself." Similarly, I have tried to show how auto-construction may work as an auto-heuristic, not just for urban theory but also for anthropological theory at large. I have offered an account of the challenges and difficulties faced by a variety of countercultural and guerrilla architectural collectives in Madrid in attempting to recuperate a vacant site in the heart of the city. The work of auto-constructing the site, of furnishing both a 
material and social ecology for it, also became a method for describing the political and epistemic liberation of the space. The inhabitants of El Campo experimented with various technologies and genres for registering the obligations and requirements, as well as the aspirations and expectations, that they deposited on the site as a space of autonomy, learning, and mutual witnessing. Their auto-construction thus functioned as a method of description and a design for theory, of the city they have at hand and of the city they would like to build: a city-specific and a city-in-abstraction. Let me close, then, with some reflections on the place that ethnography occupies amid the panoply of methods inhabiting, intermediating, and upending how the city-specific and the city-in-abstraction relate to one another.

Few distinctions have drawn as engaged and exhaustive scrutiny and criticism as that between the specific and abstract qualities of conceptual reasoning. No lesser text than The Savage Mind famously opens with a disquisition on the spurious differentiation between specific and abstract thought when applied, respectively, to primitive and scientific reasoning (Lévi-Strauss 1966, 1-9). As is well known, Claude Lévi-Strauss suggested that the savage mind is fueled by bricolage, an operation of inventiveness that draws on a heterogeneous, yet limited set of tools and materials for laying out novel arrangements with which to navigate the world. The operation of bricolage exemplified, for Lévi-Strauss (1966, 16), “a science of the concrete," where the abstract or specific qualities of conceptual maneuvering are superseded by a method of empirical pragmatics and potentiality.

The image of the bricoleur recalls the method of brico-urbanism that guerrilla architectural collectives single out as characteristic of their practice in Madrid. However, if for Lévi-Strauss $(1966,18)$ bricolage makes for an operation that lies "half-way between percepts and concepts," it has been my purpose in this article to show how in the context of guerrilla urbanism, the method of bricolage is itself auto-constructed in an operation that recursively problematizes the very status of the city as method. Thus, when people summoned the ghosts of the economic crisis at the Puerta del Sol's city in miniature or when they speculated on the oligarchic alliance between real-estate interests and corrupt politicians that haunted the future of El Campo, they were invoking an image of the city that made itself felt as both a specific and a generic presence in their lives. The generic and the specific appear entangled and muddled, and the experience of navigating and moving between them is rendered as an experience of method, of sharingwith, moving-toward, mobilizing-for, immersing-in, systematizing-out-fromfor example, through the use of specific languages and interfaces of description, 
archival and documentary technologies, or systems and infrastructures of apprenticeship. We may say that the city appears as "a figure seen twice” (Riles 2001, 91) _ an object at once specific and abstract — yet it does so only while in motion as a method in auto-construction. ${ }^{9}$

The city as method affects ethnography too, for it gets entangled in now specific, now generic recursions, with other methods and other systems of problematization. How to discern, then, what an ethnographic effect looks like today? Ethnography's own entanglement in this dazzle of recursions, I have noted, is often perceived, appropriately, as a moment of auto-dazzle, when our methods double back mischievously on their presumed efficacy. When the city is at stake, the dangers of auto-dazzle loom large in the footsteps of informality and the periphery: the discoveries of ethnography reveling in the informality of discovery. Yet what if it is the auto rather than the dazzle that the ethnographic should go after-its moment of self-construction rather than its moment of self-revelation? This is not unlike what James Holston's informants did when focusing on the culture of distinction and personality invested in each house, while keeping an eye on the dangers of copying that haunted each project. Quite literally, they seemed to be auto-constructing their own auto-dazzle. In this context, as I noted above, auto-construction functioned not as an object (housing) nor as a process (self-organization) but as a method for the city. For some scholars, this rehearses and invites reformulations of the problem of the epistemology of the urban - the categories and concepts with which to apprehend the city. Instead of lingering with this problem, though, I would invite us to consider and explore the methods, designs, and "trajectories of apprenticeships" (Pignarre and Stengers 2011, 44) through which the city and its stories auto-construct one another.

\begin{abstract}
This article recuperates the concept of auto-construction as a heuristic for anthropological theory and method. Drawing on the concept's original usage in urban studies, I suggest that auto-construction offers a handle for grasping not only how grassroots projects mobilize resources, materials, and relations in ways that are inventive and transformative of urban ecologies but that it also helps outline how theory itself is auto-constructed: the operations of problematization through which situations are navigated and designed into methods of inquiry and exploration. I read autoconstruction, in other words, as both an empirical and theoretical descriptor, a sort of auto-heuristics for thinking of the city as method. The argument is illustrated by an ethnographic account of work with guerrilla architectural and countercultural collectives in Madrid, focusing in particular on the transformation of a vacant open-
\end{abstract}


air site in the heart of the city into a self-organized community project, exploring how activists variously problematized the city as method. [auto-construction; informal urbanism; ethnographic methods; ethnographic design; infrastructures]

\section{NOTES}

Acknowledgments When I returned to Madrid in 2009 after a seventeen-year absence, the city I got to know was very different from the city I remembered having grown up in. Over the past eight years, I have been extremely lucky to find myself in the company of a group of people whose capacity to rediscover every corner of the city as a space of wonder, surprise, and possibilities is unfaltering, as is their capacity to get up every time they get knocked down, which unfortunately has happened more than a few times in the wake of the neoliberal austericide that has struck us. This text would therefore be simply unimaginable without the inspiration and accompaniment I have received from them. In particular, I want to express my deepest sympathy and gratitude to Juan López-Aranguren Blázquez, Manuel Polanco Pérez-Llantada, Rubén Lorenzo Montero, and Alberto Nanclares (Basurama); Manuel Palacio and Aurora Adalid (Zuloark); Diego Peris (Todo por la Praxis); Jacobo García Fouz and Jorge Martín (El Campo de Cebada). Tomás Sánchez Criado read a first draft of this essay, and his comments and suggestions provided much-needed direction and finesse. With characteristic wit and lucidity, Morten Nielsen engaged with an early draft of the text and invited me to rethink the scales, the structure, and the temporalities of an argument that was, up to that point, hardly recursive itself. Marilyn Strathern dazzled the text with her usual generosity as she reassured me that there was indeed scope for auto-dazzling our languages of description of the city. I would also like to express my appreciation to the Cultural Anthropology editorial collective for their critical encouragement and support throughout the editorial process. The final text has benefited enormously from the generous and attentive reading of reviewers and editors. If I leave for the end my mention of Adolfo Estalella, it is only in recognition of his magisterial role in the intellectual and methodological auto-construction of our joint ethnographic journey through Madrid during these past years.

1. The unemployment rate in San Cristóbal is $\mathbf{1 7 . 8 5}$ percent, Madrid's highest. Less than half of the neighborhood's population has any formal education, with only 4.8 percent having completed a higher education qualification. Average income in 2015 reached $€ 15,594$.

2. Here, I am inspired by Raymond Williams's (1961) well-known description of the cultural vectors - the structures of feeling - shaping class dynamics, but also AbdouMaliq Simone's $(2014,84)$ recent reappropriation of the term to describe the "urban majorities" that come together and take shape as a "densification of techniques . . . calculations, impulses, screens, surfaces . . . tears," such that "things get their 'bearings' by having 'bearing' on each other."

3. In this guise, auto-construction helps us move away from questions of representation in urban theory (see also Thrift 2008), not just by drawing attention to the vectors of affect, desire, or vitality that traverse city life (Gandolfo 2009; Simone 2010), nor by focusing on the complex, heterogeneous, and fuzzy assemblages that constantly compose and recompose the urban condition (Farías and Bender 2010; McFarlane 2011), but by paying attention to the ecologies of practice through which the city is auto-constructed as method of inquiry and exploration.

4. I hyphenate this term, although scholars like Holston do not, to highlight its recursive logic: a language of the city that does double duty as a language for the city.

5. Unemployment would keep rising to peak at 26.09 percent, or 6 million people, in 2013.

6. Note how the periphery is made to work in this context as a figure seen twice: now territory, now concept. Annelise Riles (2001) uses this phrase to describe the complex 
heuristics of the network age, where social and analytical forms often substitute for each other. Significantly, Strathern $(1999,262)$ uses the image to characterize the ethnographic moment itself, in which "either observation or analysis, either immersement or movement, may seem to occupy the entire field of attention. What makes the ethnographic moment is the way in which these activities are apprehended as occupying the same (conceptual) space." Later in the essay, I argue that it is also necessary to examine how such (conceptual) spaces are designed and auto-constructed.

7. I owe this phrase to one of the article's anonymous reviewers.

8. Aurora's final question, in the original Spanish, was “iqué significa aprender ciudad?" Aprender ciudad and hacer ciudad, learning and making cityness, have become two of the most popular idioms in use among grassroots community projects.

9. On recursion as a method in motion, see Holbraad 2012.

\section{REFERENCES}

Arecchi, Alberto

1984 "Auto-Construction in Africa." Cities 1, no. 6: 575-79. https://doi.org/10. 1016/0264-2751(84)90065-9.

Banck, Geert A.

1986 "Poverty, Politics and the Shaping of Urban Space: A Brazilian Example." International Journal of Urban and Regional Research 10, no. 4: 522-40. https:// doi.org/10.1111/j.1468-2427.1986.tb00027.x.

Boucher, Nathalie, Mariana Cavalcanti, Stefan Kipfer, Edgar Pieterse, Vyjayanthi Rao, and Nasra Smith

2008 "Writing the Lines of Connection: Unveiling the Strange Language of Urbanization." International Journal of Urban and Regional Research 32, no. 4: 989 1027. https://doi.org/10.1111/j.1468-2427.2008.00827.x.

Cáritas

2013 “VII informe del Observatorio de la Realidad Social.” Madrid: Cáritas Española. http://edit.um.es/exclusionsocial/caritas-viii-informe-del-observatorio-de-larealidad-social.

Corsín Jiménez, Alberto

2014a "The Right to Infrastructure: A Prototype for Open-Source Urbanism." Environment and Planning D 32, no. 2: 342-62. https://doi.org/10.1068/ d13077p.

2014b "Introduction. The Prototype: More than Many and Less than One." Journal of Cultural Economy 7, no. 4: 381-98. https://doi.org/10.1080/17530350.2013. 858059 .

Corsín Jiménez, Alberto, and Adolfo Estalella

2014 "Assembling Neighbors: The City as Hardware, Method, and 'a Very Messy Kind of Archive." Common Knowledge 20, no. 1: 150-71. https://doi.org/ 10.1215/0961754X-2374808.

Davis, Mike

2004 "Planet of Slums: Urban Involution and the Informal Proletariat." New Left Review, no. 26: 5-34. https://newleftreview.org/II/26/mike-davis-planet-of-slums.

2006 Planet of Slums. New York: Verso.

edumeet

2012 “Edumeet." Arquitectura Viva, no. 145: 26.

Eizenberg, Efrat

2012 "Actually Existing Commons: Three Moments of Space of Community Gardens in New York City.” Antipode 44, no. 3: 764 82. https://doi.org/10.1111/ j.1467-8330.2011.00892.x.

Farías, Ignacio, and Thomas Bender, eds.

2010 Urban Assemblages: How Actor-Network Theory Changes Urban Studies. New York: Routledge. 
Gandolfo, Daniella

2009 The City at Its Limits: Taboo, Transgression, and Urban Renewal in Lima. Chicago: University of Chicago Press.

Holbraad, Martin

2012 Truth in Motion: The Recursive Anthropology of Cuban Divination. Chicago: University of Chicago Press.

Holston, James

1991 “Autoconstruction in Working-Class Brazil." Cultural Anthropology 6, no. 4: 44765. https: / / doi.org/10.1525/can.1991.6.4.02a00020.

Holston, James, and Teresa Caldeira

2008 "Urban Peripheries and the Invention of Citizenship." Harvard Design Magazine, no. 28: 18-23.

International Labor Organization (ILO)

2015 Global Wage Report 2014/15: Wages and Income Inequality. Geneva: International Labor Organization. http://ilo.org/global/research/global-reports/global-

Iveson, Kurt wage-report/2014/lang--en/index.htm.

2013 "Cities within the City: Do-It-Yourself Urbanism and the Right to the City." International Journal of Urban and Regional Research 37, no. 3: 941-56. https:// doi.org/10.1111/1468-2427.12053.

Lévi-Strauss, Claude

1966 The Savage Mind. New York: Oxford University Press. Originally published in 1962.

Lury, Celia, and Nina Wakeford, eds.

2012 Inventive Methods: The Happening of the Social. New York: Routledge.

Marcus, George

2014 "Prototyping and Contemporary Anthropological Experiments with Ethnographic Method.” Journal of Cultural Economy 7, no. 4: 399-410. https:// doi.org/10.1080/17530350.2013.858061.

McFarlane, Colin

2011 Learning the City: Knowledge and Translocal Assemblage. Malden, Mass.: Wiley.

McGuirk, Justin

2014 Radical Cities: Across Latin America in Search of a New Architecture. New York: Verso.

Nielsen, Morten

2011 "Inverse Governmentality: The Paradoxical Production of Peri-Urban Planning in Maputo, Mozambique." Critique of Anthropology 31, no. 4: 329-58. https:// doi.org/10.1177/0308275X11420118.

Organization for Economic Cooperation and Development (OECD)

2015 "In It Together: Why Less Inequality Benefits All." Paris: OECD Publishing. https: / / doi.org/10.1787/9789264235120-en.

Pignarre, Phillipe, and Isabelle Stengers

2011 Capitalist Sorcery: Breaking the Spell. Translated by Andrew Goffey. New York: Palgrave Macmillan.

Purcell, Mark

2013 "The Right to the City: The Struggle for Democracy in the Urban Public Realm.” Policy and Politics 41, no. 3: 311-27. https://doi.org/10.1332/ 030557312 X655639.

Rabinow, Paul

2011 The Accompaniment: Assembling the Contemporary. Chicago: University of Chicago Press.

Rao, Vyjayanthi

2006 "Slum as Theory: The South/Asian City and Globalization." International Journal of Urban and Regional Research 30, no. 1: 225-32. https://doi.org/10.1111/ j.1468-2427.2006.00658.x. 
Riles, Annelise

2001 The Network Inside Out. Ann Arbor: University of Michigan Press.

Roy, Ananya

2011 "Slumdog Cities: Rethinking Subaltern Urbanism." International Journal of Urban and Regional Research 35, no. 2: 223-38. https://doi.org/10.1111/j.14682427.2011.01051.x.

Simone, AbdouMaliq

2006 "Pirate Towns: Reworking Social and Symbolic Infrastructures in Johannesburg and Douala." Urban Studies 43, no. 2: 357-70. https://doi.org/10.1080/ 00420980500146974.

2010 City Life from Jakarta to Dakar: Movements at the Crossroads. New York: Routledge. 2014 Jakarta, Drawing the City Near. Minneapolis: University of Minnesota Press.

Strathern, Marilyn

1999 Property, Substance, and Effect: Anthropological Essays on Persons and Things. New

Thrift, Nigel Brunswick, N.J.: Athlone Press.

2008 Non-Representational Theory: Space, Politics, Affect. New York: Routledge.

Turner, John F. C.

1976 Housing by People: Towards Autonomy in Building Environments. New York: Pantheon.

Turner, John F. C., and Robert Fichter, eds.

1972 Freedom to Build: Dweller Control of the Housing Process. New York: Macmillan.

Walliser, Andrés

2013 "New Urban Activisms in Spain: Reclaiming Public Space in the Face of Crises." Policy and Politics 41, no. 3: 329-50. https://doi.org/10.1332/ $030557313 \times 670109$.

Williams, Raymond

1961 The Long Revolution. London: Chatto and Windus. 